Article

\title{
Implementation of Accelerated Policy-Driven Sustainability Transitions: Case of Bharat Stage 4 to 6 Leapfrogs in India
}

\author{
Aditi Khodke ${ }^{1,2}, *\left(\mathbb{0}\right.$, Atsushi Watabe ${ }^{1}$ and Nigel Mehdi ${ }^{2}$ \\ 1 Institute for Global Environmental Strategies, Kanagawa 240-0115, Japan; watabe@iges.or.jp \\ 2 Kellogg College, University of Oxford, Oxford OX2 6PN, UK; nigel.mehdi@conted.ox.ac.uk \\ * Correspondence: khodke@iges.or.jp
}

Citation: Khodke, A.; Watabe, A.; Mehdi, N. Implementation of

Accelerated Policy-Driven

Sustainability Transitions: Case of Bharat Stage 4 to 6 Leapfrogs in India. Sustainability 2021, 13, 4339.

https://doi.org/10.3390/su13084339

Academic Editor: Jose

Navarro Pedreño

Received: 4 March 2021

Accepted: 8 April 2021

Published: 13 April 2021

Publisher's Note: MDPI stays neutral with regard to jurisdictional claims in published maps and institutional affiliations.

Copyright: (c) 2021 by the authors. Licensee MDPI, Basel, Switzerland. This article is an open access article distributed under the terms and conditions of the Creative Commons Attribution (CC BY) license (https:// creativecommons.org/licenses/by/ $4.0 /)$.

\begin{abstract}
In the face of pressing environmental challenges, governments must pledge to achieve sustainability transitions within an accelerated timeline, faster than leaving these transitions to the market mechanisms alone. This had led to an emergent approach within the sustainability transition research (STR): Accelerated policy-driven sustainability transitions (APDST). Literature on APDST asserts its significance in addressing pressing environmental and development challenges as regime actors like policymakers enact change. It also assumes support from other incumbent regime actors like the industries and businesses. In this study, we identify the reasons for which incumbent industry and business actors might support APDST and whether their support can suffice for implementation. We examine the actor strategies by drawing empirical data from the Indian national government policy of mandatory leapfrog in internal combustion engine (ICE) vehicle emission control norms, known as Bharat Stage 4 to 6 . This leapfrogging policy was introduced to speed up the reduction of air pollutants produced by the transport sector. A mixed-methods approach, combining multimodal discourse analysis and netnographic research, was deployed for data collection and analysis. The findings show that unlike the status quo assumption in STR, many incumbent industry and business actors aligned with the direction of the enacted policy due to the political landscape and expected gains. However, the degree of support varied throughout the transition timeline and was influenced by challenges during the transitioning process and the response of the government actors. The case suggests we pay more attention to the actors' changing capacities and needs and consider internal and external influences in adapting the transition timelines. This study contributes to the ongoing discussion on the implementation of APDST, by examining the dynamism of actor strategies, and provides an overview of sustainability transitions in emerging economies.
\end{abstract}

Keywords: accelerated policy-driven sustainability transitions; Asian sustainability transitions; cleaner vehicle technology; urban air pollution

\section{Introduction}

In the face of pressing environmental challenges, transitioning away from unsustainable consumption and production patterns as fast as possible is a necessity. Governments play a stewarding role in addressing these challenges, and they are increasingly pledging to achieve sustainability transitions within a pre-determined timeline. For example, the People's Republic of China has indicated to be carbon neutral by 2060 [1], and Japan and the European Union by 2050 [2]. Various cities across the C40 network have pledged to meet the World Health Organization (WHO) air quality guidelines by 2030 [3]. Notably, the timelines envisaged by governments for achieving such transitions tend to be faster than can be achieved through market mechanisms alone.

The academic community working in the field of sustainability transition research (STR) refers to government's stewarding role in accelerating sustainability transitions as an emergent approach $[4,5]$. Despite the limited empirical evidence on the success of accelerated policy-driven sustainability transitions (APDST), many prominent scholars in the field 
of STR assert the significance of such transitions in addressing pressing environmental and development challenges [6,7].

STR loosely defines an actor as an entity, be it an individual, institution, organisation, or a collective, related to transition [8]. Different actors are often grouped based on their analytical hierarchy or their timeline of being operational in socio-technical systems such as incumbents linked with regimes versus emergent actors connected with niches [9]. Multiple studies on socio-technical transition, driven by market mechanism, have underscored the resistance of incumbent regimes towards change due to their lock-in and path dependency [10]. For APDST, regime actors like policymakers and the governments enact the change through policy mechanisms. However, enacting accelerated policies alone is insufficient for transitioning, as the implementation of transition entails support from different actors [11].

The dynamic interaction of policymakers and incumbent regimes shapes and formulates the courses of transitions. So far, there is limited understanding of the response of other incumbent actors, particularly from the businesses and industries towards APDST. The studies that assert the significance of APDST largely take the support from other incumbent regime actors for granted, as a matter of compliance [12] or guided selection [7]. The urgent need to understand actor strategies is evidenced in the STR literature [5].

This research revisits the reasons for which the incumbent actors other than policymakers support APDST, if at all, and examine if support is sufficient for implementing the APDST. Comprehending the strategies of these actors enables the examination of the implementation of transition as well as to critically assess the assertion of the significance of APDST.

In this study, we examined the implementation of APDST by gathering empirical data from the Indian national-government-led mandatory leapfrog in the internal combustion engine (ICE) vehicle emission control norms, Bharat Stage 4 (BS4) to Bharat Stage 6 (BS6). We assessed the strategies of incumbent automotive industry actors and policymakers in response to these APDST by looking into the historical and present contexts and their discursive activities on social media; and identified reasons for incumbent industry actor's support, including their volatility of support; and their struggles in transitioning. We find that actor strategies eventually determine the directions and limitations of the accelerated transition.

The next section provides an overview of the transition scholarship and locates the novelty of APDST in the STR literature. Section 3 further elaborates on the Indian case and Section 4 explains the methodology for data collection and analysis. Section 5 sets out the findings, and Section 6 discusses our findings and compares them with the assumptions of STR. Section 7 concludes the article and suggests direction for further research.

\section{Literature Review}

\subsection{Key Concepts in Transition Studies}

The transition studies propose frameworks to harness sustainable development through technologies, practices, and governance [10]. Since the transition studies gained traction in the 1990s, they have taken holistic approaches towards comprehending change, accumulating insights about changes across the socio-technical systems, and providing insights to bring about transformative systemic shift [13].

The underpinning and seminal works of Kemp [14] and Rip and Kemp [15] argued that because technologies are embedded in societal systems, any technology change is socio-technical in nature. Changes in societal systems accompany a change in technological systems. To delineate the mechanisms of changes in socio-technical transitions, Rip and Kemp [15] defined an analytical hierarchy in socio-technical systems, namely niche, regime, and landscape, which can be interpreted as micro, meso, and macro levels. Geels [16] elaborated on this hierarchy to propose the multi-level perspectives (MLP) framework.

During the past three decades, transition theories have matured through gaining additional insights from multiple theoretical approaches: Industrial and evolutionary 
economics, science and technology studies, political science, and cultural studies [17], and proposed pertinent frameworks with differing foci and objectives, namely the MLP $[16,18]$, Strategic Niche Management (SNM) [19], Technological Innovation Systems (TIS) [20,21], and transition management [22]. Moreover, researchers are proactive in advancing existing frameworks [23] and proposing new frameworks as necessary [7]. However, despite such developments, the conceptual underpinnings of transitions being socio-technical, and their analytical hierarchies, remain prevalent in transition studies.

Niches are considered incubators of new technologies and innovations. In contrast, regimes are the dominant intertwining of culture, institutional structures, actors, networks and practices that resist change [11], and landscape is where technologies become a norm and widespread [16]. This assumption has allowed researchers to consider the different positions and powers of actors in a specific system. The micro, meso, and macro levels offer different forms of stabilities where actors, networks, and their alignment determines the change in the socio-technical systems leading to the adoption of a certain technology or spread of an everyday practice [24,25].

\subsection{Change in Application of Transition Studies: Development of STR}

From predominately focusing on the uptake of individual technologies [18], transition studies have since focused on the uptake of sustainability-oriented innovation, technologies, and governance [26]. In particular, post-2000s, policymakers have actively applied the insights of transition studies to guide socio-technical transitions. An example of its application in addressing sustainability challenges is the Dutch government's national environmental policy plan (NM4) launched in 2001. This plan extensively used transition studies to set long-term orientation and short-term policies for addressing sustainability challenges like climate change, biodiversity loss, and exploitation of resources [27]. Academic works involving sustainability-oriented transitions are referred to as sustainability transition research (STR) [28].

\subsection{Assumptions on the Pace of Transition}

Though interdisciplinary crossovers can be seen [29] as the scholarship matured, transition research emerged in Northern Europe, and to date, remain dominated by Western scholars, particularly from the Netherlands. Most of them cover Northern European case studies, while the transitions outside Europe remain relatively unexplored [30].

Pioneers of transition scholarship concur that socio-technical transitions are multidecadal, long-term processes of change $[10,14,16]$. There are a few reasons for such unequivocal affirmation of temporality. Firstly, past transitions, for technical advancements in technology [18,31], particularly for improvements in design and performance and therefore in user-friendliness [14], mainly in the 19th and 20th centuries, required multiple decades. Secondly, as technology takes hold in a market, its price reduces, making it more affordable and further contributing to its uptake [14].

Such assumptions derived from technological transitions in developed economies do not capture globalisation's influence. Assessing transition timelines in the context of globalisation is particularly significant. Importantly, as many Asian countries have radically transitioned from import substitution development models in post-colonial times to export-led economies in the 1980s and 1990s [32], the interaction with global markets has accelerated the pace of technology development [33]. Factors like technology transfer, international knowledge and learning networks, and reduction in technology costs through outsourcing in emerging economies all accelerate the pace of technology transition; thus, the transition timeline should not be taken for granted [6].

Moreover, the Euro-centric focus has arguably diverted researchers' attention to the potentially different socio-economic contexts of transitions. For example, studies have found that the transition processes in Asian contexts deviate from transition studies [33] due to the governance structures that are yet to be fully democratic [34], often having ineffective regulatory policies and inadequate support from the private sector and civil society 
actors [35]. The governments often lead transitions in close collaboration with a handful of actors from the private sector [32], while many actors across the unorganised sectors are often not represented in transition processes [34,35]. The historical contexts in these countries also influence actors' configuration and roles from local, national, and international societies, as is shown in the energy transitions in Thailand and the Philippines [36].

\subsection{Limited Attention and Assumptions on the Role of Actors}

STR loosely defines an actor as any entity, be it an individual, institution, organisation, or a collective, related to transition [8]. Different actors are often grouped based on their analytical hierarchy or their timeline of being operational in socio-technical systems such as incumbents linked with regimes versus emergent actors connected with niches [9]. However, the definitions of niche, regime, and landscape have often been ambiguous, lacking established indicators to describe those [37]. This lack of conceptual clarity makes it harder to delineate the hierarchical boundaries of one level from another and the interlinkages among them while a particular technology becomes widely accepted [38].

With such a loose grouping of the actors in three levels, transition theorists argue that technological transitions emerge on a small scale and gain legitimacy through market mechanisms [13]. These assumptions are drawn from observations of the uptake of new technologies. STR rely on the overarching assumptions that incumbent actors are unlikely to change $[5,10]$ and that emergent actors are necessary to enact change [28]. Incumbent actors are also referred to as 'dominant actors' [39] or 'existing actors' [22], and are considered to be locked-in unsustainable socio-technical regimes. Due to their vested interests, they resist change [10]. This resistance to change is referred to as the 'inertia'. These actors are assumed to change only through external pressure but not through their willingness to change [12]. On the other hand, emergent actors are referred to as 'new actors', 'outside actors', and 'niche actors' [40]. The 'frontrunners' among these emergent actors are referred to as 'change agent' and 'champion' [41]. As these words suggest, they are usually understood as the actors initiating experimentation and radical innovations in the protective spaces [42].

The categorisation of actors into broad groups like incumbent and emergent provides an overview of transitions. As a result, STR has provided limited attention to individual actor strategies [43]. Despite the significance of actors [8], the role of individual actors in transition processes has received relatively little attention in the existing literature [9,41].

However, due to socio-technical systems' highly entrenched nature, particularly in urban settings, where applying analytical hierarchies poses challenges [44]. Studies during the last decade revealed that not only niche actors but also policy and incumbent business at the regime level engage in the discursive practices to negotiate the creation of the sociotechnical visions associated with the transitions [45] in specific sectors like transportation management [46] or renewable energy [47]. Actors involved in a particular transition process do not just lead, follow, or resist it. A more careful observation of actors' strategies will help us capture how they participate in the sense-making of a transition to take the best advantage while minimising the negative impacts in transitioning.

\subsection{Accelerated Policy-Driven Sustainability Transitions (APDST)}

The differing strategies of actors are worth further attention, particularly in the context of the faster transitions initiated or strongly supported by the governments. Sustainable technological transitions are often aligned with the mandate of governments to address urgent challenges to sustainable development. Pressure from multilateral organisations and international coalitions further create an urgency to address development challenges [4]. Therefore, government actors are equally interested in mainstreaming sustainable technologies. This push from government actors through directed policies could accelerate the pace of transitions compared with market-driven transitions [4]. The guided selection of sustainable technologies could overcome the time-intensive process before becoming mainstream [20]. Although there is limited empirical evidence that policy-driven transitions 
accelerate the pace of transition, Kern and Rogge's (2016) compelling argument [4] is shared by other scholars. Hekkert et al. [7] propose a framework for mission-oriented transitions, or the government-led accelerated policy-driven sustainability transition (APDST), where regimes guide the socio-economic systems toward a desired future within a specific time, like a mission. Whereas the empirical evidence of their success and implementation are both recognised areas for further research $[4,48]$, APDST cases would enable researchers and policymakers to broaden their scopes beyond the market-led (or niche-driven) transitions of a sector that typically take decades. Moreover, research on implementation strengthens the understanding of the necessary implementation support and can contribute to better policy design. The assessment of actor strategies among policymakers and recipients [48] serves this purpose.

\subsection{Need for Further Research on the Power Relations in APDST}

The cases where governments took significant roles in transitions suggest that we pay more nuanced attention to the dynamics of positions of and relationships among the actors at all levels or, in other words, the dimension of politics [49]. Bulkeley et al. [50] and Wolfram and Frantzeskaki [51] argue that because political landscapes influence processes of socio-technical change, transition studies needs to be coupled with the lens of political ecology. Their remark is in line with broader criticisms of transition studies in overlooking the significance of political processes [52]. It contributes to Geels et al.'s suggestion [29] of the need for further research on political aspects of transitions. Even transition management research that emphasises interactions among actors through debates across strategic activities and negotiations at the tactical activities [22] is not free from this criticism [53], as it often assumes that all actors are inherently equal. Interests of different actors align with one another [27].

A more careful examination of power relations enables us to consider the dynamics of shaping the directions, paces, and even meanings of transitions, combined with the previous point about the different actors' strategies and the accelerated transitions led by governments.

Accelerated transitions [7] look as if governments make actors go straight for the pre-determined goals in the fixed timeline on the surface. However, past transition cases indicate that actors with differing needs and visions negotiate and gradually shape goals, timelines, and even meanings of the transitions over time [47]. Such dynamics should also apply to accelerated transitions. Still, some actors may be kept out of the collective sense-making of the forced goals in a short time and thus abide by an uncomfortable share of benefits and costs. Therefore, particularly in the study of accelerated transitions, we need to pay more attention to the cases where actors having different powers and strategies interact with others so that the ongoing transitions are most beneficial to them. For example, political actors may be interested in maintaining power relations in favour of specific incumbent actors while guiding the transitions [49]. Accelerated transitions can potentially be "successful" in achieving tangible "changes" in technologies or practices at the cost of placing burdens on or even excluding some of the actors having weak powers to influence the market or policies [54].

The remainder of the paper describes how APDST are enacted, applied, and responded to through analysing the discursive practices of the actors in the case of leapfrog in vehicle emission standards in India.

\section{Case Study}

The booming cities in India are facing many pressing environmental challenges. One is the alarming levels of air pollution [55]. The severity of this problem can be assessed through the World Health Organization's listing, which identified 14 Indian cities among the world's 20 most-polluted cities considering ambient air quality [56]. Within Indian cities, vehicles are one of the main reasons for the poor ambient air quality [55,57]. 
In India, the number of privately owned vehicles is one of the root cause of air pollution [58]. Each year, over 2 million cars and two-wheeled vehicles are sold within the country [59]. The majority of these vehicles are internal combustion engine (ICE)driven. Inefficient ICE powertrains emit high levels of pollutants like hydrocarbons, carbon monoxide, nitrogen oxides, sulphur oxides, and particulate matter [60]. Poor air quality is the cause of 4.2 million premature deaths worldwide [61]. In India, the public health vulnerabilities due to air pollution from vehicles are listed in Table 1.

Table 1. Health impact of pollutants from vehicles.

\begin{tabular}{|c|c|c|}
\hline $\begin{array}{c}\text { Vehicular Air Pollutants } \\
{[60]}\end{array}$ & $\begin{array}{l}\text { Health Impacts from Air } \\
\text { Pollutants [62] }\end{array}$ & $\begin{array}{l}\text { Ambient Air Quality Index } \\
\text { at Anand Vihar, New Delhi } \\
\text { on } 15 \text { January } 2020 \text { [63] }\end{array}$ \\
\hline Hydrocarbons & Irritation in eye, nose, and throat & Not monitored \\
\hline Carbon monoxide & Damage to central nervous system & Satisfactory \\
\hline Nitrogen oxides & Damage to lungs & Satisfactory \\
\hline Sulphur oxides & Respiratory diseases & Good \\
\hline Particulate Matter (PM) & $\begin{array}{l}\text { Asthma, bronchitis, increased risk } \\
\text { of preterm birth and morbidity rate }\end{array}$ & $\begin{array}{c}\text { PM 2.5: Poor } \\
\text { PM 10: Moderate }\end{array}$ \\
\hline
\end{tabular}

Considering the severity of the health crisis [62], addressing air pollution from vehicles is a priority for urban sustainability in India [55]. The Fossil Fuel Free Streets Declaration, signed by 34 cities across the Global South and North [64], is a testimony that the challenges of urban transport, including vehicular pollution, are not limited to Indian cities. Many cities across the world face similar challenges to different degrees.

Cities respond to the challenge of air pollution from vehicles by banning older ICE vehicles from the city centre, or even prohibiting their use altogether [65]. Other solutions include production side measures, like improving vehicle technology through the interventions of the national government [66].

The Indian National Ministry of Road Transport and Highways; Ministry of Heavy Industries and Public Enterprises; Ministry of Environment, Forest and Climate Change; and the Ministry of Petroleum and Natural Gas, in 2016, choose to improve the vehicle technology by introducing a draft policy for mandatory leapfrog from Bharat Stage 4 (BS4) vehicle emission control standard to Bharat Stage 6 (BS6) vehicle emission control standard [67]. They decided to skip the Euro5-equivalent BS5 emission control norms and proposed the introduction of BS6 emission control norms by 2020 to curb pollution from vehicles [57]. Applicable to both petrol and diesel vehicles, the BS6 norms were expected to reduce emissions of nitrogen, sulphur oxides, and particulate matter from new vehicles.

The BS4 to BS6 leapfrog included three sub-transitions: First, a restriction on the sales of new BS4-compliant vehicles after 1 April 2020; second, the manufacturing and sales of BS6-compliant vehicles and auto-components by 1 April 2020; and third, the availability of BS6-compliant fuel in parallel with the vehicle launch.

The pace of BS6 transition timeline was four years ahead of the former political regime's, the United Progressive Alliance (UPA), planned timeline in 2024, and one year before the incumbent political regime's, the National Development Alliance (NDA), initially planned timeline of $2021[67,68]$. The BS4 norm is equivalent to the European emission control standard Euro4, and BS6 complies with Euro6B and part of Euro6D [69]. The Euro4-to-Euro6B transition occurred over a span of nine years, whereas the BS4 to BS6 leapfrog was introduced in 2016, finalised in 2018, and was expected to be completed in 2020.

The next section discusses the research methods used to identify the actors and the assessment of the implementation through actor strategies. 


\section{Research Method}

This research examined the implementation of APDST by assessing the actor strategies in response to the enacted the BS4 to BS6 vehicle emission control transition in India. Before examining the actor strategies towards the concerned transition, examining the political landscape for the development of emission control norms was perceived essential, in line with Section 2.6. We first started with the historical analysis of vehicle emission control norms in India. Then, following STR's prevalent research method of aggregating multimodal data to reconstruct transition trajectories, we examined policy documents on the BS4 to BS6 transition, and related news articles. This method, combined with the historic analysis of vehicle emission control standard, enabled us to identify automotive regime actors that can be representative of the incumbent automotive industry supply chain. This method posed limitations in collecting procedural data, which is crucial for assessing actor strategies. Hence, we sought the additional research method of social media data collection and analysis.

To summarise the research method involved four steps: Step 1: Assessing the history of vehicle emission control norms in India; Step 2: Aggregating multi-modal data on the BS4 to BS6 transition; Step 3: Social media analysis for data collection on actor strategies; and Step 4: Social media data analysis.

\subsection{Step 1: Assessing the History of Vehicle Emission Control Norms in India}

Political ecology is a significant yet understudied aspect of STR. We examined the development of vehicle emission control standard against the political landscape from its inception in India in the early 1990s. This inquiry led to further analysis of the development of automobile manufacturing industry in India in post-colonial times, which ultimately resulted in assessing the timeline from 1947 to 2018. We referred to research articles, reports, and policy documents. This analysis provided an overview of the critical junctures in India's incumbent automobile manufacturing regime, political landscape, its influence on the development of vehicle emission control standard, and automotive industry actors that can be representative of the incumbent regime. The result of this step is detailed in Section 5.1.

\subsection{Step 2: Aggregating Multi-Modal Data on the BS4 to BS6 Transition}

In STR, a commonly used research method involves multimodal data analysis to reconstruct the trajectories of transitions and to establish a causal relationship within the sequence of key events and transition processes $[17,46]$. Transition studies rely on the literature of research articles, policy documents, news, business reports, and books [16,43].

The BS4 to BS6 leapfrog was introduced in a draft policy document published by the Ministry of Road Transport and Highways in February 2016. Automobile manufacturers association contested the draft policy to negotiate the transition timeline by approaching the Supreme Court of India. The Supreme Court of India passed the final verdict in October 2018 to finalise the transition timeline, mandating to be completed before April 2020. This verdict underlined the support from two incumbent automobile manufacturers for stringent vehicle emission control norms. News articles reporting this policy change provided details on the involved political actors from the national ministries $[67,68]$.

Based on Sections 4.1 and 4.2, 18 actors from the national ministries, individual automobile manufacturers, and auto industry associations were identified. Actors were selected considering the suggestion to identify incumbent actors from the supply chains to include both upstream and downstream actors [21] (details provided in Section 5.2).

\subsection{Step 3: Social Media Analysis for Data Collection on Actor Strategies}

This research was conducted between 2018 to 2020, concomitant with the implementation of the BS4 to BS6 transition. Published research articles on this topic were very limited (See [70]). Similarly, limited news outlets focusing on the automotive industry reported updates on this transition, and attention from the mainstream news media was limited. 
Available data indicated the outcome of the ongoing discussion between the automotive industry regime actors and the political actors, but seldom elaborated on procedural information, which was perceived necessary for examining the process of policy implementation and changes in actor strategies.

Previous studies in STR assessed actor strategies by interviewing actors to gather information on procedural data after the transition was realised [24,71]. This research required real-time and procedural data on actor strategies, which would entail frequent and multiple interviews with the identified actors. Due to the influential positions of the identified 18 actors, frequent and multiple interviews were not feasible. Moreover, part of this research was conducted amidst the COVID-19 pandemic, which affected the availability of actors for interviews. An alternative research method of social media analysis was selected to obtain real-time procedural data.

Data collection via social media is a novel, since 2008, but increasingly popular research method in social science, business and management, environment, and multidisciplinary researches [72]. In STR, so far, only a limited number of studies have used social media for data collection, such as Henshilwood et al. [73]. Such studies have used online ethnographic research methods, also known as netnography, which allows the study of communities created via digitally mediated social interactions [74]. Use of social media for data collection enables gathering user-generated data, through multiple methods like participant observation, actively participating in online activities and interacting with users [73], or by combining qualitative and quantitative methods through text mining [75].

Here, we used text mining due to its effectiveness in extracting large volumes of data, overcoming research biases due to the researchers' self-identity, saving time required for data collection, and providing easy access to user-generated data in a pre-determined timeframe [75,76].

The selection of social media platforms depends on their user base, permission to access data from the platform, and the type of data each platform can provide [75]. To assess actor strategies, a preferred platform was one that is used to express opinions on socio-political subjects, with an assumption that it would include opinions about the BS4 to BS6 leapfrog. Facebook and Twitter are used to share opinions [75]. Between these two platforms, Twitter users are more likely to share opinions on political matters [77]. Twitter's cap on text volume, 280 characters, makes it manageable to engage with the data through text analysis.

Despite the preference for Twitter, it was crucial to verify whether the selected Indian policy and automotive industry actors actually use it. In India, the use of social media platforms by politicians to share their opinions is fairly recent, starting from 2014; this is unlike the U.S., which heavily used social media platforms like Twitter in the 2008 elections [78]. Across the NDA-led national government, Twitter is the most-used social media platform by almost all the national ministers and ministries [77]. Researchers manually verified if other identified actors use Twitter or not, and most were avid users. Only official accounts managed directly by the selected actors were considered.

A total of 25,758 tweets between October 2018 to April 2020 were collected using R programming's 'twitteR' and 'Rtweet' packages. On average, between 500 and 3200 past tweets were extracted from the selected actors. All the collected data were exported to Microsoft Excel. Though the draft BS4-to-BS6 policy was introduced in 2016, it was only finalised in October 2018. Hence, the timeline from 2018 to 2020 was selected.

\subsection{Step 4: Social Media Data Analysis}

Kozinets et al. [74] cautioned against text mining combined with data analysis software, which overshadows the researcher's ability to engage with the data. This research used text mining as a data extraction tool. The extracted data were carefully organised following a systematic search query [76]. The systematic search query was conducted based on the recurring terms identified related to the Bharat Stage emission control standard. The identified keywords were BS-VI, BSVI, BS6, BSIV, Bharat Stage, BS-IV, and BS4. 
The critique on the authenticity of social media data [79] was addressed by the selection of Twitter, as identities of the actors are not hidden [80], secondly by collecting data from official accounts [81], thirdly by manually curating truncated data, and lastly by data triangulation against other information sources like news, speeches of the identified actors at automobile industry events, blogs, and industry reports, where available [82].

Twitter has tweet and retweet functions. A tweet is the user-generated data, whereas a retweet further distributes already-tweeted data [78]. The differences between the two are ambiguous, as users may include additional information when retweeting. Both tweets and retweets reflect a user's position when broadcasting textual discourse [83]. Broadcasting a text discourse can enable engagement with a wider audience, deliberate mobilising information, and can create a chain reaction [78]. We analysed both tweet and retweet functions.

The tweets were analysed using Gee's toolkit to identify relevant text-analysis strategies [84]: Particular attention was paid to language in use, which helped in identifying the targeted audience of the tweet; persuasive discourses [85]; and the lexical styles that reflect the power dynamics and the relative position of the actor in a wider societal sphere.

In carrying out this research, the ethical implications were carefully considered. Only publicly available published data were collected and analysed. Twitter data were collected with approval, using a standard application-programming interface (API).

\section{Results and Findings}

This section provides further information on how different incumbent actors from the automotive industry supply chain and the government responded to the mandatory and accelerated policy-driven transition. Here, we share findings from the historical analysis on vehicle emission control norms, introduce the selected actors related to the BS4 to BS6 transition and their analysed Twitter timelines, the key events in the BS4 to BS6 transition trajectory, and the actors' strategies in response to those.

\subsection{Development of Vehicle Emission Control Standard in India}

The pace of motorisation in India has been swift. This rapid pace, coupled with inefficient vehicle technology, has led to alarming levels of air pollution in Indian cities [36]. However, addressing vehicular emission was not only an environmental and public health challenge, but also a policy tool to advance foreign collaboration, export potential, and industrial competitiveness.

Emissions from vehicles have reportedly been a concern for Indian cities since the 1970s. The national development model of protectionist strategies and the inward-looking growth of the automotive industry through import substitution led to inferior quality vehicles that generated 2-3 times higher emissions, resulting in high levels of air pollution in cities [76]. According to the Japanese automobile manufacturer Suzuki Motors, the Indian automotive industry in the 1970s was technologically 30 years behind the world's most recent technology [86].

The 1980s remain the most significant decade in India for addressing air pollution from vehicles and the development of vehicle technology. The collaboration with Japanese automobile manufacturers in the 1980s led to improved fuel efficiency and technology among Indian automobile and auto component manufacturers [87]. Soon after this collaboration, India's Air Act was enacted in 1981, which identified emissions from vehicles as one of the causes of air pollution. In 1986, India's first comprehensive environment policy was enacted, providing for the first time limits on permissible emissions from vehicles [88]. The 1980s also remain significant for environmental activism, particularly after the 1986 Bhopal gas plant tragedy that caused over 3000 deaths, half a million injuries, and created deformities among new-born children in subsequent decades. The first public interest litigation against air pollution caused by vehicles was filed in 1985 [88].

Despite the attention paid to air pollution from vehicles and deliberate efforts to improve the technology through foreign collaborations, India's old vehicle fleet, poorly 
maintained vehicles, and the high number of two-stroke vehicles were identified as reasons for poor air quality in urban areas [89].

The Indian government launched their first vehicle emission control norms in 1990 [90]. This was also when the European Union adopted and mandated the Euro1 emission control norms for all member states. In 1991, India adopted a New Economic Policy, which changed the discourse of India's inward-looking import-substitution economy toward an economy based on the principles of liberalisation, globalisation, and privatisation.

In post-colonial times, the United Progressive Alliance (UPA) mostly led the Indian national government. In 1998, for the first time, India was governed by the majority party the New Development Alliance (NDA). The NDA government expanded the UPA government's liberalisation policies, particularly by taking active measures to promote the export potential of Indian industries [91], as well as encouraging foreign investment and promoting joint ventures between foreign and Indian automobile manufacturers. The number of automobile manufacturers in India grew as well. Within this context, sustaining the growth of the automobile manufacturing industry by only catering to the domestic market would have posed a challenge; hence, increasing export potential of the automobile manufacturing industry was one of the co-benefits of adopting the globally recognised Euro vehicle emission control norms in 2000. The national government mandated the nationwide adoption of Euro1, domestically known as India 2000 norms [60]. These norms were later renamed the Bharat Stages (BSs).

The BS2, BS3, and BS4 norms were adopted in a phased approach: First in metropolitan cities, and gradually across rest of the country in 2005, 2010, and 2017, respectively [60]. The B6 norms were initially planned to be adopted in 2024 but their adoption was advanced and finalised for 2020, citing the urgency to address air pollution from vehicles as an intergenerational equity issue.

\subsection{Selected BS4 to BS6 Transition Actors}

\subsubsection{Policy Actors}

The BS4 to BS6 draft policy to leapfrog the emission control standard was introduced in 2016 at a joint meeting among the national Ministry of Road Transport and Highways; Ministry of Heavy Industries and Public Enterprises; Ministry of Environment, Forest and Climate Change; and the Ministry of Petroleum and Natural Gas. The Supreme Court of India finalised and mandated this policy in 2018 and played a crucial role in addressing grievances of the automotive industry actors during the implementation phase. Hence, we selected the policy actors as the four ministries and the apex court.

It was observed that some ministers from the above-mentioned national ministries were in charge of multiple other national ministries. Hence, the ministers and ministries were treated as two separate sources of data.

\subsubsection{Incumbent Automotive Regime Actors}

After 1947, the growth of the domestic automobile manufacturing industry was largely aided by the Indian government's protectionist policies. They drove foreign automobile manufacturers out of the country [87] and retained a handful of automobile manufacturing companies, all led by Indian entrepreneurs who had newly diversified their businesses from steel manufacturing to automobile manufacturing [92]. These companies included both commercial and passenger vehicle manufacturers. Passenger vehicle manufacturers that were operating since 1947 and continued to be in operation in 2020 included Mahindra \& Mahindra, TATA Motors, Bajaj Auto, and Hindustan Motors.

The 1950s-1970s was the formative phase of the vehicle and component manufacturing industry. The formation of industry associations like the Automotive Component Manufacturers Association (ACMA) in 1959, the Society of Indian Automobile Manufacturers (SIAM) in 1960, and the Federation of Automobile Dealers Associations (FADA) in 1964 are indicative of the consolidation of the Indian automotive industry. 
Toward the end of the 1970s and early 1980s, the Indian national government, led by the United Progressive Alliance (UPA), opened India's inward-looking automotive industry to collaborate with technologically advanced Japanese automobile and component manufacturers. Indian-government-owned car manufacturing company Maruti Udyog [86] and Suzuki Motors established a joint venture, Maruti Suzuki, which still continues to be India's largest automobile manufacturer by market share.

The 1970s and 1980s saw an increased demand for two-wheeled vehicles for the growing middle class population [93]. TVS Motors launched India's first two-wheeled mopeds and, later, in collaboration with Suzuki Motors, ventured into the motorcycle manufacturing business.

The number of actors within the Indian automobile manufacturing industry has continuously grown between 1947 and 2020. Distinguishing between incumbent and emergent actors remains difficult [20]. Regardless, TATA Motors, Mahindra \& Mahindra, and Maruti Suzuki remain among India's top five car manufacturers, whereas Bajaj Auto and TVS Motors are among the top two-wheeler manufacturers. In the Supreme Court's verdict, TVS Motors and Bajaj Auto were identified as the incumbent automobile manufacturers who supported stringent vehicle emission control norms. The three industry associations, ACMA, SIAM, and FADA, continue to be the source of the automobile industry's collective voice. ACMA represent $800+$ auto component manufacturers, SIAM represent $40+$ large automobile manufacturers operating in India, and FADA represent 15,000 dealers and 30+ regional dealer's associations [94-96]. These three industry associations, together with Government of India established the Automotive Skills Development Council (ASDC) in 2019, which is expected to play a key role in the capacity-building of the automobile industry towards new technological transitions [97].

To summarise, five prominent incumbent automobile manufacturers, and four industry associations were selected to represent the response of incumbent automobile regime actors towards the BS4 to BS6 leapfrog. These actors are referred to as incumbents based on the status quo definition of incumbency in STR literature [9].

\subsection{Twitter Analysis}

The Ministry of Heavy Industries and Public Enterprises appears not to have a Twitter account. Similarly, due to the Minister of Petroleum and Natural Gas's frequent Tweeting, the extracted data using Twitter's standard API could only collect Tweets between July 2020 and May 2020, as this timeline was beyond the scope of this research, so the position of the minster could not be taken into account.

For the automotive industry actors, it was observed that the automobile manufacturer Mahindra \& Mahindra frequently referred to their chief's, Mr. Anand Mahindra, Twitter account, so the data collection was expanded to include the Tweets from the chief. Similarly, we considered including the tweets from the presidents of SIAM, ACMA, FADA, ASDC, and other automobile manufacturers; but the industry associations in most cases retweeted the positions of their presidents, which were collected from the association's account. None of the other automobile manufacturers referred to the company presidents or any particular person.

This resulted in data collection from 17 actors from the ministries, ministers, industry associations, automobile skill enhancement organisation, and automobile manufacturers. The list of all the selected actors and their analysed Twitter timelines is indicated in Table 2. 
Table 2. Selected actors and their analysed Twitter timeline.

\begin{tabular}{lll}
\hline Type of Actor & Name of the Actor & $\begin{array}{l}\text { Date of Retrieved Tweets } \\
\text { (DD/MM/YYYY) }\end{array}$ \\
\hline & Ministry of Heavy Industries and Public Enterprises & None \\
Minister of Heavy Industries and Public Enterprises and & $01 / 11 / 2019$ to $01 / 04 / 2020$ \\
Minister of Environment, Forest and Climate Change & $30 / 09 / 2018$ to $02 / 04 / 2020$ \\
Policymakers & Ministry of Road Transport and Highways & $10 / 03 / 2019$ to $01 / 04 / 2020$ \\
& Minister of Road Transport and Highways & $01 / 10 / 2018$ to $01 / 04 / 2020$ \\
& Ministry of Environment, Forest and Climate Change & $26 / 01 / 2019$ to $01 / 04 / 2020$ \\
& Ministry of Petroleum and Natural Gas & None \\
\hline Minister of Petroleum and Natural Gas & $01 / 10 / 2018$ to $01 / 04 / 2020$ \\
& SIAM & $01 / 10 / 2018$ to $01 / 04 / 2020$ \\
& ACMA & $01 / 10 / 2018$ to $03 / 04 / 2020$ \\
FADA & $01 / 10 / 2018$ to $01 / 04 / 2020$ \\
ASDC & $07 / 12 / 2019$ to $01 / 04 / 2020$ \\
Maruti Suzuki India Limited & $09 / 03 / 2020$ to $01 / 04 / 2020$ \\
& Tata Motors Limited & $03 / 09 / 2018$ to $05 / 04 / 2020$ \\
& Mahindra \& Mahindra Limited & $22 / 10 / 2018$ to $01 / 04 / 2020$ \\
Chief of Mahindra \& Mahindra Limited & $23 / 01 / 2019$ to $01 / 04 / 2020$ \\
& Bajaj Auto Limited & $15 / 10 / 2019$ to $01 / 04 / 2020$ \\
\hline
\end{tabular}

The Minister of Environment Forest and Climate Change, who also led the Ministry of Heavy Industry and Public Enterprises, did not Tweet on either BS4 or BS6 emission control norms. The Ministry of Road Transport and Highways mostly tweeted in Devnagari script, which was beyond the scope of this research. SIAM tweeted most frequently about the BS4 to BS6 transition, followed by the Ministry of Petroleum and Natural Gas, FADA, and TVS Motors. The frequency of tweets is indicated in Figure 1.

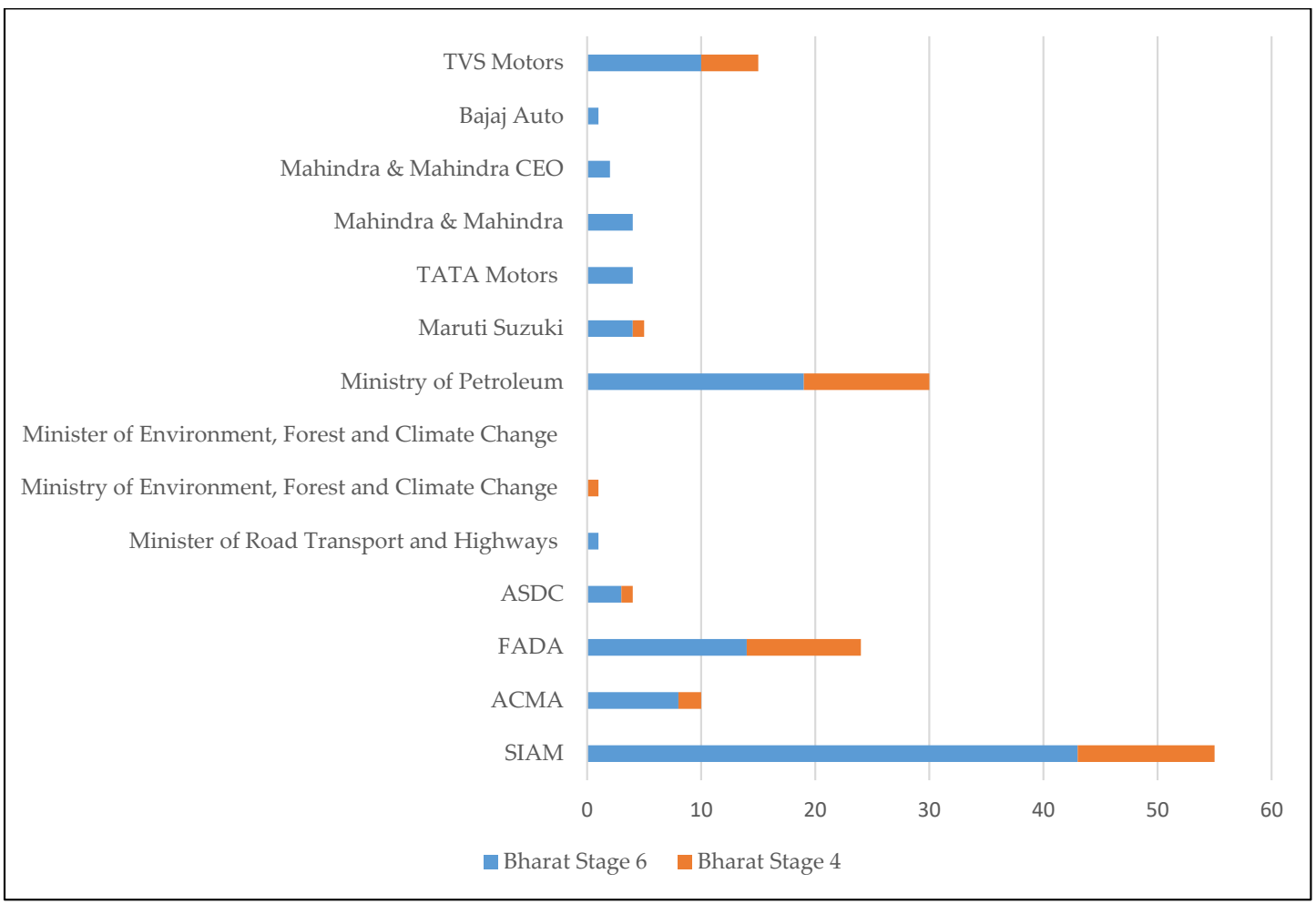

Figure 1. Frequency of tweets on BS4 and BS6. 


\subsection{BS4-to-BS6 Transition: Key Events}

Based on aggregating the analysed Twitter data and its linked news articles, speeches of actors at automobile industry events, blogs, industry reports, and the policy documents, the following key events were identified. Some of these events were initiated by the identified actors, while others were actor's reactions to externalities. Figure 2 provides a quick overview of key events.

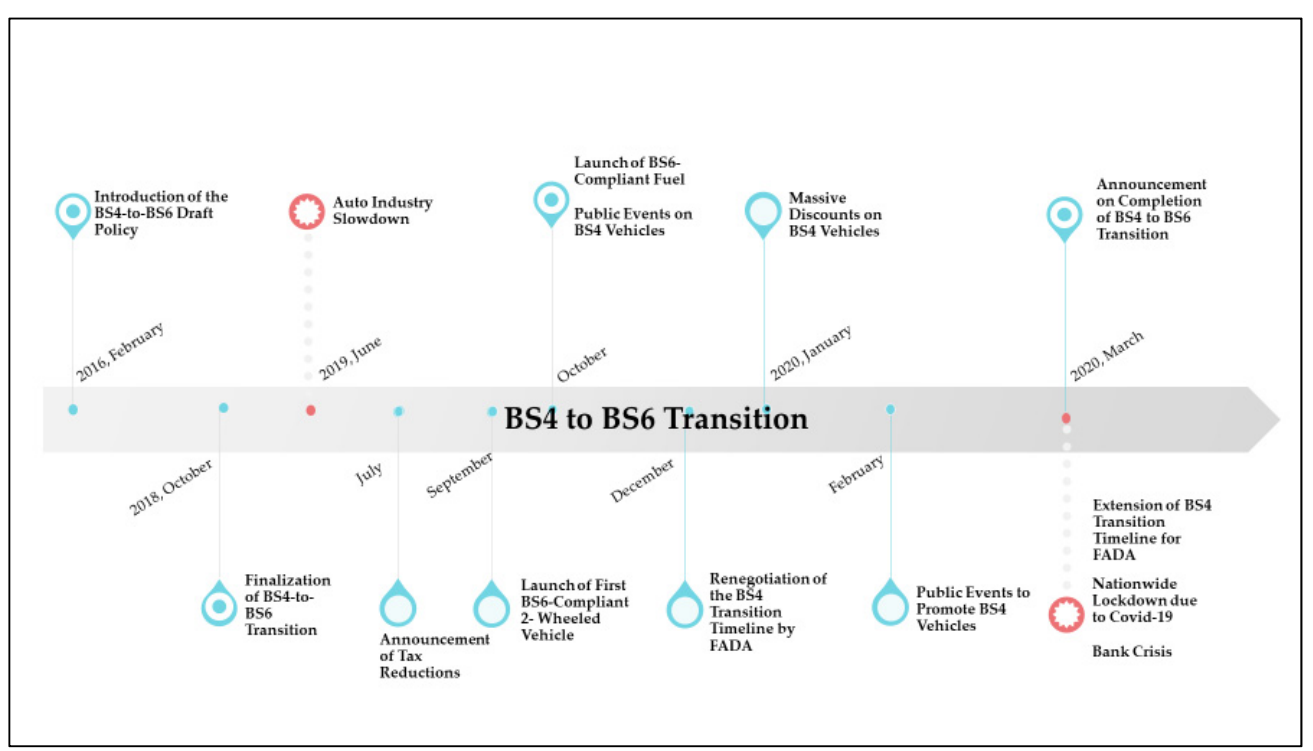

Figure 2. Overview of the BS4 to BS6 transition timeline.

\subsubsection{Introduction of the BS4-to-BS6 Draft Policy (February 2016)}

The draft policy for BS4-to-BS6 leapfrog, introduced in 2016 as an outcome of an interministerial meeting, was contested by the Society of Indian Automobile Manufacturers (SIAM). SIAM appealed to the Supreme Court of India to negotiate the timeline on the ban on the sales of new BS4 vehicles. They underlined that after the introduction of BS6compliant fuels, it will take their members three to six months to completely shift to BS6 vehicles and clear BS4 inventory; hence, the timeline for fuel availability and BS4 vehicle ban shall be one after the another [98]. SIAM represented its members, comprising about 40 Indian and foreign automobile manufacturers operating in India.

\subsubsection{Finalisation of BS4-to-BS6 Transition (October 2018)}

The Supreme Court of India rejected SIAM's appeal in October 2018 in a seminal judgement that supported the national government's decision to adopt BS6 from 2020 and prohibiting the sales of new BS4 vehicles beyond 31 March 2020. The court cited an urgency to act against air pollution and framing air pollution as an intergenerational equity issue [98].

\subsubsection{Automobile Industry Slowdown (June 2019)}

In 2019, the Indian automobile industry experienced one of the worst and unforeseen slowdowns. SIAM and FADA shared about the slowdown on their Twitter accounts. The plunge of $31 \%$ in the sales of passenger vehicles compared to the previous year indicates the magnitude of the crisis [99].

\subsubsection{Announcement of Tax Reductions (July 2019)}

The National Ministry of Finance addressed some of SIAM's and FADA's demands by reducing tax and easing the corporate social responsibility expenditure to include R\&D activities [100]. After these measures, SIAM became optimistic for the growth in sales. 


\subsubsection{Public Events on BS4 (September 2019)}

Along with the industry slowdown, the confusion among consumers about the validity of BS4-compliant vehicles throughout their registration period was a concern. This lowered the sales of BS4 vehicles. News about these events was shared on Twitter by SIAM, FADA, and the Minister of Road Transport and Highways.

\subsubsection{Launch of First BS6 Compliant Vehicle (September 2019)}

Honda Motors was the first to launch BS6 compliant two-wheeled vehicles, almost six months ahead of the national government's mandated timeline. The Minister of Road Transport and Highways shared about the launch on his Twitter account.

\subsubsection{Launch of BS6-Compliant Fuel (October 2019)}

BS6-compliant fuel was introduced in October 2019. The Ministry of Petroleum and Natural Gas shared this news on their Twitter account. This assured the automobile manufacturers and helped them plan for their BS6 inventories.

\subsubsection{Renegotiation of the BS4 Transition Timeline by FADA (December 2019)}

Members of FADA shared on Twitter that they had high levels of unsold BS4 vehicle inventory due to the auto industry slowdown and approached Supreme Court to renegotiate the timeline.

\subsubsection{Massive Discounts on BS4 Vehicles (January 2020)}

Promotion activities for BS4 vehicles surged. BS4 vehicles were promoted as technically on par with BS6 vehicles and lighter on the (customers) pockets. Individual automobile manufacturers like Maruti Suzuki, Tata Motors, TVS Motors, FADA, and ASDC shared about the discounts and promoted BS4 vehicles on their Twitter accounts.

\subsubsection{Advancement of Transition Timeline (February 2020)}

Some sub-national governments and financial institutes set their own timelines to stop registration and lending for the BS4 vehicles ahead of the government's timeline. This was shared by SIAM in their Twitter feed.

\subsubsection{Bank Crisis (March 2020)}

One of the leading private banks in India was placed under a moratorium, limiting regular banking operations. Indian consumers rely up to $74 \%$ on external finance when purchasing automobiles [101], which further affected the BS4 inventory. This was tweeted by FADA.

\subsubsection{Covid-19 National Lockdown (24 March 2020)}

The Indian government announced a countrywide lockdown due to the COVID-19 pandemic, which further reduced the days available to liquidate BS4 inventory. The twowheeled dealers, which are often small and medium-sized businesses, had relatively higher BS4 inventories.

5.4.13. Extension of the Sale of BS4 Vehicles: (27 March 2020)

Due to the COVID-19-induced countrywide lockdown, the Supreme Court of India allowed the members of FADA to sell their unsold vehicle inventory affected by the pandemic [102].

5.4.14. Announcement on Completion of the BS4 to BS6 Transition (1 April 2020)

ACMA, SIAM, ASDC, and the Ministry of Petroleum and Natural Gas announced the successful completion of transition on Twitter. 


\subsubsection{Evaluation of Transition Timeline Extension (July 2020)}

The Supreme Court Reflected upon the extension to sell BS4-compliant vehicles and concluded that some dealers misused the extension; as a result, more BS4 vehicles were sold than anticipated [102].

\subsection{Actor Strategies}

As explained in Section 3, the BS4-to-BS6 leapfrog involved three sub-transitions: Availability of BS6-compliant fuel and vehicles and the ban on the sales of new BS4compliant vehicles after 31 March 2020. The actors' strategies in response to key events are elaborated in the following sections. Figure 3 provides an overview of the dynamic positioning of actors.

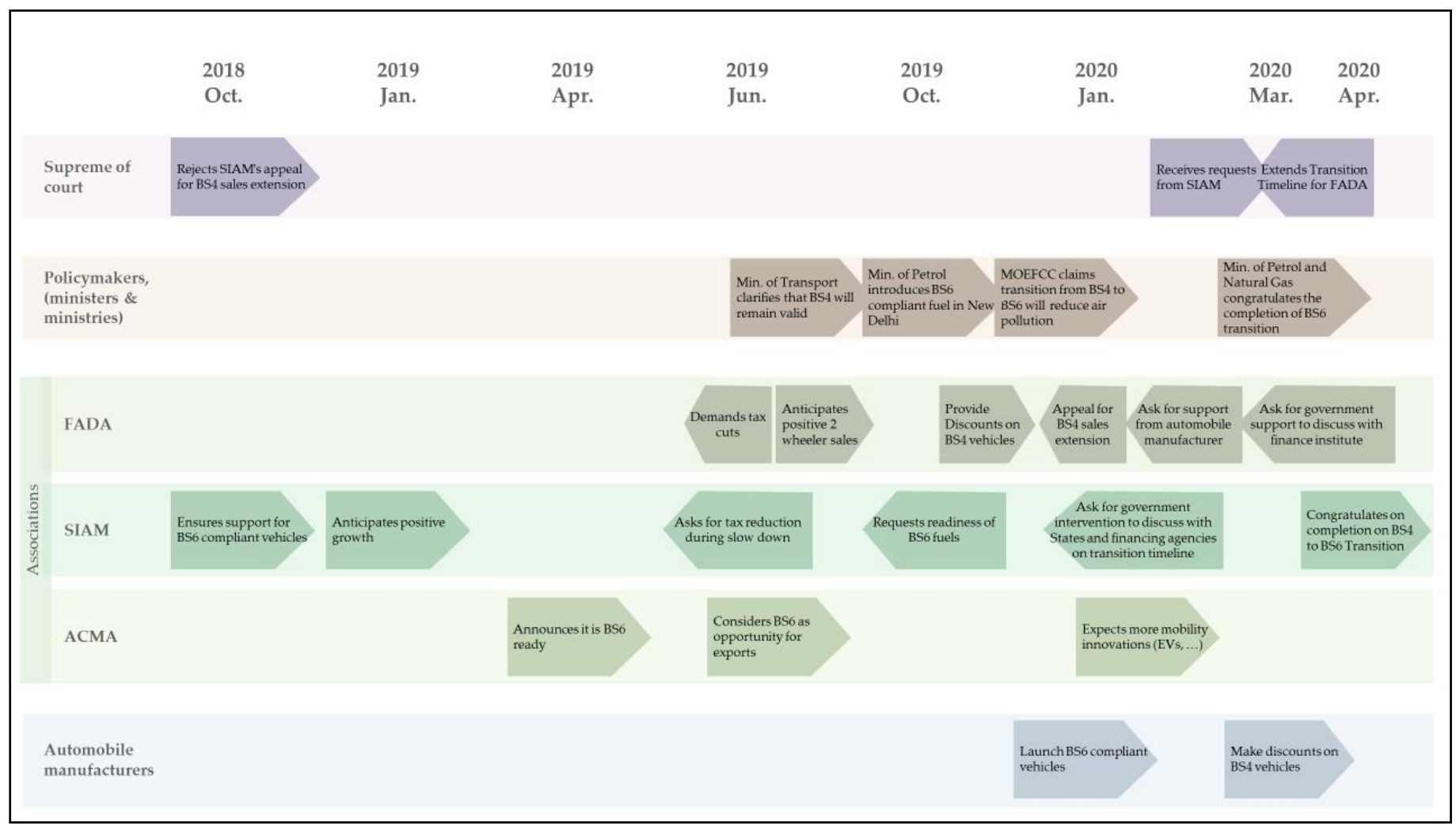

Figure 3. Dynamic positioning of actors.

\subsubsection{Introduction of the BS4-to-BS6 Draft Policy (February 2016)}

- SIAM, as a collective, resisted the transition timeline for the ban on the sales of BS4 vehicles.

- Many of SIAM's members were already manufacturing and exporting BS6-compliant vehicles; the economic gains of continuing with BS4 vehicles were higher [98].

5.5.2. Finalisation of BS4-to-BS6 Transition (October 2018)

- $\quad$ Anticipating the rejection of the appeal, SIAM stated its support for the BS4-to-BS6 transition even before the Supreme Court of India's final judgement in October 2018 on their Twitter account.

- $\quad$ SIAM indicated their support for the transition by assuring the launch of BS6-compliant vehicles by the national government's proposed timeline.

- $\quad$ ACMA, FADA, and ASDC expressed their support on Twitter for the transition during the implementation process. 


\subsubsection{Automobile Industry Slowdown (June 2019)}

Despite the sluggish growth from the beginning of 2019 until June 2019, SIAM and FADA anticipated positive sales.

- $\quad$ SIAM and FADA demanded tax reductions on Twitter from July 2019 to promote vehicle sales for both BS4 and upcoming BS6 vehicles.

- $\quad$ On Twitter SIAM expressed conditionality on meeting the BS6 timeline due to the lack of clarity for the availability of BS6-compliant fuel from the national government.

- ACMA was the first among the automobile industry supply chain to tweet readiness for the BS4-to-BS6 transition in June 2019.

5.5.4. Announcement of Tax Reductions (July 2019)

- Members of SIAM and FADA tweeted their appreciation for the tax reductions and indicated optimism toward growth in vehicle sales because of the festive season in India.

5.5.5. Launch of First BS6 Compliant Vehicle (September 2019)

- Individual members of SIAM, like Honda Motors, introduced the first BS6-compliant two-wheeled vehicle.

5.5.6. Public Events on BS4 Vehicles (September 2019)

- Government actors like the National Minister of Road Transport and Highways clarified the validation of BS4 vehicles post March 2020.

- SIAM organised sessions to clarify the technical differences between BS4 and BS6 vehicles.

5.5.7. Launch of BS6-Compliant Fuel and Vehicles (October and November 2019)

- The National Ministry of Petroleum and Natural Gas introduced BS compliant fuel in the National Capital Region of India. They underscored the following environmental benefits of the BS4 to BS6 transition.

“Leapfrogging from BS-IV to BS-VI is a testimony of our Govt's commitment to reduce vehicular pollution and ensure a cleaner India" (Ministry of Petroleum and Natural Gas, 15 November 2019, Twitter).

- $\quad$ SIAM appreciated the efforts of the Ministry and remained optimistic toward the BS4-to-BS6 leapfrog.

- $\quad$ SIAM shared the benefits of the BS4-to-BS6 leapfrog and accentuated the importance of this transition toward reducing air pollution.

- $\quad$ Mahindra \& Mahindra, TVS Motors, TATA Motors, Maruti Suzuki, and Bajaj Auto launched BS6-compliant vehicles ahead of the transition time.

5.5.8. Renegotiation of the BS4 Transition Timeline by FADA (December 2019)

- FADA approached the Supreme Court of India to seek an extension for the sales of BS4-compliant vehicles until the stocks of BS4 vehicles purchased before 31 March 2020 were over.

5.5.9. Massive Discounts on BS4 Vehicles (January-February 2020)

- Members of FADA and SIAM, like TVS Motors, gave massive discounts on BS4 vehicles.

- $\quad$ FADA organised public discussion sessions to clarify technical confusion regarding BS4 and BS6 vehicles.

5.5.10. Advancement of Transition Timeline (February 2020)

SIAM approached the Supreme Court of India to ensure all the sub-national governments and financial institutes follow the nationally determined transition timeline. 


\subsubsection{Bank Crisis (March 2020)}

FADA sought intervention from the Minister of Road Transport and Highways and Minister of Finance to help them unload the BS4 inventories.

\subsubsection{Covid-19 National Lockdown (24 March 2020)}

Members of SIAM continued to supply BS4 vehicles to FADA despite their multiple requests.

- $\quad$ Some members of SIAM exported their unsold BS4 inventories.

- Many members of FADA could not sell the BS4 vehicles.

\subsubsection{Extension of Transition Timeline (27 March 2020)}

- $\quad$ The Supreme Court granted extension to FADA to sell the unsold BS4 stocks, manufactured before 31 March 2020.

- Many dealers registered the vehicles under their employees' names and sold them beyond the transition timeline as second-hand stock.

\subsubsection{Announcement on Completion of the BS4 to BS6 Transition (1 April 2020)}

- SIAM, ACMA, and the Ministry of Petroleum and Natural Gas indicated completion and success of the BS4-to-BS6 leapfrog.

- $\quad$ FADA requested the help of the National Minister of Road Transport.

- $\quad$ FADA did not succeed in selling its BS4 inventory before 31 March 2020.

\section{Discussion}

Our findings confirm Kern and Rogge's assumption that regime actors, like policymakers, can speed up the pace of transition by addressing sustainability challenges through directed policies [4], which, if left to market mechanisms, could take multiple decades to achieve [14]. It also supports the observation in policy studies that any enacted policies achieve some degree of success [103]. The findings also illustrate Berkhout's [104] assertion that in industrial economies where both production and consumption supply chains are linked, environmental problems are addressed through technological solutions.

STR assumes that incumbent socio-economic regimes and their related actors are path-dependent and locked-in to unsustainable practices, so they resist change [10]. A few studies, like Penna and Geels [12], Berggren et al. [105], and Shiroyama and Kajiki [106], identified that there are deviations to this assumption. Penna and Geels [12] associated the support from incumbent actors with external pressures such as those from the policymakers, which are not necessarily due to the actors' own strategy. This research contributes to the deviation. For the Indian case, the introduction of policy did play a role in aligning all the actors toward the directed sustainability transition at an accelerated pace through guiding the socio-technical system towards a pre-determined future. Yet, the incumbent actors did not just submissively follow the transition policy but eventually adjusted their positions to it after the transition was finalised and during its implementation, as was shown by some actions, such as initial contestation to the timeline, the production of BS6-compliant vehicles before the transition timeline, communication of the benefits of the transition, and the responses in the face of the lack of compatible fuel and economic crisis.

Support from incumbent regime actors is dynamic, and the degree of support can vary throughout the transition timeline. This dynamism was in response to externalities and key events in the transition trajectory. It identifies that through negotiation with the other actors and addressing some externalities, actors can reposition themselves either as those proactively moving the transitions or those opportunistically resisting.

The next sub-sections elaborate further on the reasons for support to APDST and the dynamic positioning that influenced the support. 


\subsection{Reasons for Support from Incumbent Actors}

The deviation in the positions of incumbent actors from the mainstream assumption in the STR is thought to be due to two factors: The socio-political landscape in India, and the anticipated co-benefits of policy transitions.

In India's post-colonial development trajectories, different national governments have collaborated with indigenous entrepreneurs in establishing a domestic automobile manufacturing industry and in realising national development strategies. Despite the change in the political regime, the national government worked closely with incumbent automotive industry actors [87,92], and have mostly enacted policies to foster growth of the automobile manufacturing regime. A similar relationship between the political regime and incumbent actors was observed across other Asian countries like Korea, Thailand, and Japan [32]. This observation underlines the significance of considering the political landscape and development trajectories [52] before assuming the position of the incumbent actors.

The Bharatiya Janata Party led New Development Alliance (NDA) national government enacted the APDST by leapfrogging the BS5 vehicle emission norms. Before enactment of this policy, the NDA government's 2014 election manifesto indicated making India a 'Global Manufacturing Hub' and creating an 'innovation and technology driven society', among others. The Indian automobile manufacturing industry is one of the key sectors identified by the NDA government to realise this manifesto. Moreover, the NDA government projected the Indian automobile manufacturing industry to be world's third largest automobile manufacturing base by 2026 [107]. To realise these aspirations, adopting one of the world's most contemporary vehicle emission control norms, on par with the European manufacturers, had anticipated economic and symbolic benefits, while banning the BS4 vehicles and fuel had environmental benefits.

The support from incumbent automobile manufacturers was crucial for the success of the BS4 to BS6 transition as they are among the most powerful actors of the incumbent regime whose strategies directed the component manufacturers and dealers. As most of the analysed automobile manufacturers were active in exports, transitioning to BS6 emission norms would further strengthen their export potential. Hence, the sub-transition to manufacture BS6 vehicles was well received by the incumbent regime due to their anticipated benefits. However, the resistance came from giving upon the immediate economic gains through domestically selling BS4 vehicles, for which the pressure from the actor like the Supreme Court helped in gaining support from the incumbents.

Depending on the political landscape and the anticipated benefits of transitions, the incumbent regime's actors are likely to support directed transitions. Similarly, the actors positioned themselves in the expectation of future gains. Even though the transitions were enacted as part of a policy to address air pollution, there were multiple benefits associated with achieving this socio-technical transition. This observation is congruent with the anticipated co-benefits associated with sustainable development, particularly in addressing the problem of air pollution [108]. This also supports the idea that sustainability transitions have multiple co-benefits, which, when they are quantified and communicated effectively [109], create an impetus to address sustainability challenges [108]. In line with Berkhout [104], this confirms that incumbent actors could align with transition visions as long as the benefits of the transitions are communicated amongst all actors.

The following subsections delves further into the reasons for dynamic positions of incumbent actors and the key considerations for APSDT implementation.

\subsection{Dynamic Position of Incumbent Actors}

In STR, actors are often grouped based on the analytical hierarchy they belong to, or the time they have been operational in those analytical hierarchies, for example, regime vs. niche actors or incumbent vs. emergent actors. Such terms deflect our attention from dynamism in actors' positions during the implementation period. The dynamic positioning of incumbent actors in response to the key events during the transition timeline was revealed by assessing the actor strategies. Despite the support from different actors in the 
automobile industry supply chain and various national ministries, the implementation of the BS4-to-BS6 leapfrog encountered different challenges, and accordingly, the actor's degree of support for the transition varied. Moreover, actors like members of the FADA could not transition within the pre-determined timeline. The key reasons are discussed below.

\subsubsection{Systemic Interdependencies}

In addition to the changes in vehicle technology, the BS4-to-BS6 transition depended on the availability of BS6-compliant fuels. This mandate came under the Ministry of Petroleum and Natural Gas. India has both publicly owned and private oil refineries. Since the introduction of the BS4-to-BS6 draft policy, SIAM expressed concerns about the transition timeline. According to them, for the implementation of the transition, BS6-complaint fuels should be made available three to six months before the automobile manufacturers shift their production line to BS6 vehicles. However, the lack of information on the availability of BS6 fuel until October 2019 created challenges for the manufacturers to plan for BS6 vehicles, and they continued with surplus BS4 vehicles.

As opposed to the transition timeline planned by the national government, some subnational governments and financing agencies set their own transition timelines, prohibiting the registration and lending for BS4 vehicles before 31 March 2020. To address the lack of coordination between national and sub-national governments, SIAM sought the Supreme Court's intervention.

The burden of the BS4 vehicle surplus and the changes in transition timeline was first borne by the members of SIAM and more so by the members of FADA.

\subsubsection{Unforeseen Externalities}

Externalities can hamper the implementation of accelerated policy transitions. During the transition timeline for BS4 to BS6, the slowdown in auto industry sales further created a surplus of BS4 vehicles in the supply chains for both the manufacturers and the dealers. SIAM's support for transition weakened, and they demanded tax reductions for vehicles. FADA supported SIAM's demand. However, the support from SIAM was regained after the national Ministry of Finance introduced tax cuts.

Members of FADA, being downstream actors of the supply chain, suffered more and could not unload the BS4 inventories; they approached the Supreme Court to seek extension for the sales of BS4 vehicles. Toward the end of the transition timeline in March 2020, the surplus was exacerbated by the enactment of a countrywide lockdown by the national government due to the COVID-19 pandemic. The Supreme Court granted a last-minute extension, three days before the end of transition timeline.

\subsubsection{Non-Negotiable Timeline Revealed Power Asymmetries}

The pre-determined and non-negotiable timeline underscored the power asymmetries within the automotive industry. Actors with limited capacities to negotiate suffered during the transition, as powerful actors succeeded to transition by imposing the cost of transition. In 2018, the Supreme Court of India mandated the BS4-to-BS6 transition to be completed by 1 April 2020. Though the timeline for sales and registration was common for all actors, meeting this timeline depended on mutual support among different actors along the supply chain. Upstream actors like auto components manufacturers, members of the ACMA, were well-prepared for the transition and delivered the BS6-compliant parts ahead of the transition timeline. However, despite repeated requests from the dealers to the automobile manufacturers, the dealers received stocks of BS4 vehicles until March 2020, which they were unable to sell. The two-wheel vehicle dealers, which are often small- and medium-size businesses, had limited capacity to negotiate with automobile manufacturers. They continued to receive BS4 vehicle stocks until the end of the transition timeline, making them unable to get rid of old stocks, and pleading support from policymakers.

The above examples indicate that though different incumbent regime actors supported the transition, their degree of support varied across the transition timeline. It was influenced 
by the challenges during the implementation process and the response of government actors in addressing those challenges. These challenges revealed the lack of coordination and power asymmetries. It underscores that enacting policy-driven transition is a multi-level and multi-actor process; sustained support for the accelerated policies requires deliberate efforts throughout the implementation process [110]. The leapfrogging from BS4 to BS6 looked successful with the support from the incumbent industry. However, it was a sleek success putting costs to actors in weaker positions and forced them to find out loopholes such as the registration of BS4 vehicles in their employees' names and selling it later as a second-hand stock.

\section{Conclusions}

Existing literature in STR postulates the resistance from incumbent regime actors to transition, APDST, the emergent approach in STR, assumes the support from incumbent regime actors as policymakers enact the change. This research elaborates further on what makes the incumbent regime actors, mainly from the industry and business, support APDST, and how their strategies influence each other in the face of externalities hindering the transition

This study reinstates the significance and potential of APDST in the addressing pressing environmental challenge.

We find that support from incumbent actors is not only due to the compliance towards enacted policies. The past and present relationship between industrial-political actors and anticipated co-benefits through transitioning influences actor strategies in response to APDST. Yet, sustaining the support from incumbent regime actors needs continued efforts from the government due to the challenges incurred in transitioning.

Though policy implementation challenges are often regarded as outcomes of failed policy coordination and coherence $[5,110]$, this research finds that if systemic interdependencies, unforeseen externalities, and non-negotiable transition timelines revealing power asymmetries are not addressed sufficiently then, some actors could not fulfil the requirements within the pre-determined timeline, and can make the success of APDST questionable.

We recommend accounting for the dynamic positioning of the regime actors to deepen the understanding of the challenges of implementing APDST. This can enable a more reflexive approach towards sustainability transition that revisits the changing capacities and needs of the actors, internal and external influences, and can adapt the transition timelines accordingly. In the absence of a carefully planned APDST, the success of transition can be questionable.

Along with contributing to the recognized research gap on the implementation of APDST, this research provides empirical evidence on the dynamism of actors during transition trajectories, which hitherto remain largely unaccounted. The research method of Twitter data analysis provides an alternative to study the process of transitioning in real-time. Moreover, this study also contributes to the geographic diversity of the STR by drawing insights of APSDT in emerging economies.

The limitation of this research is twofold. Firstly, conclusions are primarily drawn based on the stated position of actors rather than their actual positions. The study partly addressed such a limitation through data triangulation, but due to the specificity of the empirical case, a limited number of data were available for triangulation. Secondly, the study only assessed the positions of well-recognised actors mentioned in the literature. In particular, the actor strategies of informal sector actors are under-represented.

As a way forward, studies in STR considering using social media analysis can benefit from combining it with interviews to verify the actor's stated position. Combining other forms of data collection to include informal sector actors [34] is highly recommended. We relied on Twitter's standard API for data collection, which capped the number of data collected. A more extensive database could contribute to strengthening these research findings. 
Author Contributions: Conceptualisation, A.K.; methodology, A.K. and N.M.; data collection and analysis, A.K.; writing-original draft preparation, A.K. and A.W.; writing-review and editing, A.K., A.W., and N.M.; visualisation, A.K.; funding acquisition, A.W. All authors have read and agreed to the published version of the manuscript.

Funding: The Environment Research and Technology Development Fund (S-16-3: JPMEERF16S11630) of the Environmental Restoration and Conservation Agency of Japan, funded the development of this manuscript.

Institutional Review Board Statement: Ethical review and approval were waived for this study. The data used in this research were based on publicly available published data collected from secondary government sources, news articles and from Twitter. Twitter data was collected with approval, using a standard application programming interface (API). Apart from Twitter, no permissions were needed or sought, and there are no ethical issues raised by this work as defined by the University of Oxford's Research Ethics.

Informed Consent Statement: Not applicable.

Data Availability Statement: No new data were created or analyzed in this study. Data sharing is not applicable to this article.

Conflicts of Interest: The authors declare no conflict of interest.

\section{References}

1. Myers, S.L. China's Pledge to Be Carbon Neutral by 2060: What It Means-The New York Times. Available online: https://www. nytimes.com/2020/09/23/world/asia/china-climate-change.html (accessed on 27 March 2021).

2. Tsukimori, O. Japan Faces High Costs in Achieving Suga's 2050 Carbon Neutrality Target I The Japan Times. Available online: https:/ / www.japantimes.co.jp/news/2020/11/09/business/japan-2050-carbon-neutrality-costs/ (accessed on 27 March 2021).

3. C40 35 Cities Unite to Clean the Air Their Citizens Breathe, Protecting the Health of Millions. Available online: https://www.c4 0. org / press_releases /35-cities-unite-to-clean-the-air-their-citizens-breathe-protecting-the-health-of-millions (accessed on 27 March 2021).

4. Kern, F.; Rogge, K.S. The pace of governed energy transitions: Agency, international dynamics and the global Paris agreement accelerating decarbonisation processes? Energy Res. Soc. Sci. 2016, 22, 13-17. [CrossRef]

5. Markard, J.; Geels, F.W.; Raven, R. Challenges in the acceleration of sustainability transitions. Environ. Res. Lett. 2020, 15, 081001. [CrossRef]

6. Sovacool, B.K. Energy Research \& Social Science How long will it take? Conceptualizing the temporal dynamics of energy transitions. Energy Res. Soc. Sci. 2016, 13, 202-215. [CrossRef]

7. Hekkert, M.P.; Janssen, M.J.; Wesseling, J.H.; Negro, S.O. Mission-oriented innovation systems. Environ. Innov. Soc. Transit. 2020 34, 76-79. [CrossRef]

8. Farla, J.; Markard, J.; Raven, R.; Coenen, L. Technological Forecasting \& Social Change Sustainability transitions in the making: A closer look at actors, strategies and resources. Technol. Forecast. Soc. Chang. 2012, 79, 991-998. [CrossRef]

9. Fischer, L.B.; Newig, J. Importance of Actors and Agency in Sustainability Transitions: A Systematic Exploration of the Literature. Sustainability 2016, 8, 476. [CrossRef]

10. Köhler, J.; Geels, F.W.; Kern, F.; Markard, J.; Onsongo, E.; Wieczorek, A.; Alkemade, F.; Avelino, F.; Bergek, A.; Boons, F.; et al. An agenda for sustainability transitions research: State of the art and future directions. Environ. Innov. Soc. Transit. 2019, 31, 1-32. [CrossRef]

11. Roberts, C.; Geels, F.W.; Lockwood, M.; Newell, P.; Schmitz, H.; Turnheim, B.; Jordan, A. The politics of accelerating low-carbon transitions: Towards a new research agenda. Energy Res. Soc. Sci. 2018, 44, 304-311. [CrossRef]

12. Penna, C.C.R.; Geels, F.W. Multi-dimensional struggles in the greening of industry: A dialectic issue lifecycle model and case study. Technol. Forecast. Soc. Chang. 2012, 79, 999-1020. [CrossRef]

13. Geels, F.W.; Schot, J. Typology of sociotechnical transition pathways. Res. Policy 2007, 36, 399-417. [CrossRef]

14. Kemp, R. Technology and the transition to environmental sustainability. The problem of technological regime shifts. Futures 1994, 26, 1023-1046. [CrossRef]

15. Rip, A.; Kemp, R. Technological change. Hum. Choice Clim. Chang. 1997, 2, 327-400.

16. Geels, F.W. Technological transitions as evolutionary reconfiguration processes: A multi-level perspective and a case-study. Res. Policy 2002, 31, 1257-1274. [CrossRef]

17. Caniëls, M.C.J.; Romijn, H.A. Strategic niche management: Towards a policy tool for sustainable development. Technol. Anal. Strateg. Manag. 2008, 20, 245-266. [CrossRef]

18. Geels, F.W. The Dynamics of Transitions in Socio-technical Systems: A Multi-level Analysis of the Transition Pathway from Horse-drawn Carriages to Automobiles. Technol. Anal. Strateg. Manag. 2005, 17, 445-476. [CrossRef] 
19. Kemp, R.; Truffer, B.; Harms, S. Strategic Niche Management for Sustainable Mobility. In Social Costs and Sustainable Mobility. ZEW Economic Studies; Rennings, K., Hohmeyer, O., Ottinger, R.L., Eds.; Physica: Heidelberg, Germany, 2000; Volume 7, pp. 167-187.

20. Hekkert, M.P.; Suurs, R.A.A.; Negro, S.O.; Kuhlmann, S.; Smits, R.E.H.M. Functions of innovation systems: A new approach for analysing technological change. Technol. Forecast. Soc. Chang. 2007, 74, 413-432. [CrossRef]

21. Bergek, A.; Jacobsson, S.; Carlsson, B.; Lindmark, S.; Rickne, A. Analyzing the functional dynamics of technological innovation systems: A scheme of analysis. Res. Policy 2008, 37, 407-429. [CrossRef]

22. Loorbach, D. Transition Management for Sustainable Development: A Prescriptive, Complexity-Based Governance Framework. Governance 2010, 23, 161-183. [CrossRef]

23. Elzen, B.; Van Mierlo, B.; Leeuwis, C. Anchoring of innovations: Assessing Dutch efforts to harvest energy from glasshouses. Environ. Innov. Soc. Transit. 2012, 5, 1-18. [CrossRef]

24. Wolfram, M. The Role of Cities in Sustainability Transitions: New Perspectives for Science and Policy. In Quantitative Regional Economic and Environmental Analysis for Sustainability in Korea; Springer: Singapore, 2016; pp. 3-22. [CrossRef]

25. Hargreaves, T.; Longhurst, N.; Seyfang, G. Understanding Sustainability Innovations: Points of Intersection between the Multi-Level Perspective and Social Practice Theory; Science, Society and Sustainability (3S) Research Group Working Paper; University of East Anglia: Norwich, UK, 2012.

26. Markard, J.; Raven, R.; Truffer, B. Sustainability transitions: An emerging field of research and its prospects. Res. Policy 2012, 41, 955-967. [CrossRef]

27. Kemp, R.; Rotmans, J.; Loorbach, D. Assessing the Dutch energy transition policy: How does it deal with dilemmas of managing transitions? J. Environ. Policy Plan. 2007, 9, 315-331. [CrossRef]

28. Loorbach, D.; Frantzeskaki, N.; Thissen, W. Technological Forecasting \& Social Change Introduction to the special section: Infrastructures and transitions. Technol. Forecast. Soc. Chang. 2010, 77, 1195-1202. [CrossRef]

29. Geels, F.W.; Hekkert, M.P.; Jacobsson, S. The dynamics of sustainable innovation journeys. Technol. Anal. Strateg. Manag. 2008, 20, 521-536. [CrossRef]

30. Temenos, C.; Nikolaeva, A.; Schwanen, T.; Cresswell, T.; Sengers, F.; Watson, M.; Sheller, M. Ideas in motion: Theorizing mobility transitions an interdisciplinary conversation. Transfers 2017, 7, 113-129. [CrossRef]

31. Turnheim, B.; Geels, F.W. Regime destabilisation as the flipside of energy transitions: Lessons from the history of the British coal industry (1913-1997). Energy Policy 2012, 50, 35-49. [CrossRef]

32. Rock, M.; Murphy, J.T.; Rasiah, R.; Van Seters, P.; Managi, S. Technological Forecasting \& Social Change A hard slog, not a leap frog: Globalization and sustainability transitions in developing Asia. Technol. Forecast. Soc. Chang. 2009, 76, 241-254. [CrossRef]

33. Berkhout, F.; Angel, D.; Wieczorek, A.J. Sustainability transitions in developing Asia: Are alternative development pathways likely? Technol. Forecast. Social Chang. 2009, 76, 215-217. [CrossRef]

34. Zusman, E.; Lee, S.Y.; Nakano, R.; Sano, D.; Lualon, U.; Nugroho, S.B. Governing Sustainability Transitions in Asia: Cases from Japan, Indonesia and Thailand. 환경사회학연구 ECO Transl. Environ. Sociol. Res. 2014, 18, 115-150.

35. Mah, D.; van der Vleuten, J.M.; Ip, J.C.M.; Hills, P. Governing the transition of socio-technical systems: A case study of the development of smart grids in Korea. Energy Policy 2012, 45, 133-141. [CrossRef]

36. Marquardt, J.; Delina, L.L. Reimagining energy futures: Contributions from community sustainable energy transitions in Thailand and the Philippines. Energy Res. Soc. Sci. 2019, 49, 91-102. [CrossRef]

37. Bilali, H. El The Multi-Level Perspective in Research on Sustainability Transitions in Agriculture and Food Systems: A Systematic Review. Agriculture 2019, 9, 74. [CrossRef]

38. Berkhout, F.; Verbong, G.; Wieczorek, A.J.; Raven, R.; Lebel, L. Sustainability experiments in Asia: Innovations shaping alternative development pathways? Environ. Sci. Policy 2010, 13, 261-271. [CrossRef]

39. Loorbach, D.; Oxenaar, S. Counting on Nature Counting on Nature. Available online: https://drift.eur.nl/wp-content/uploads/ 2018/02/Counting-on-Nature.-Transitions-to-a-natural-capital-positive-economy.pdf (accessed on 10 April 2020).

40. Geels, F.W. Ontologies, socio-technical transitions (to sustainability), and the multi-level perspective. Res. Policy 2010, 39, 495-510. [CrossRef]

41. Wittmayer, J.M.; Avelino, F.; Van Steenbergen, F.; Loorbach, D.; van Steenbergen, F.; Loorbach, D. Environmental Innovation and Societal Transitions Actor roles in transition: Insights from sociological perspectives. Environ. Innov. Soc. Transit. 2017, 24, 45-56. [CrossRef]

42. Smith, A.; Raven, R. What is protective space? Reconsidering niches in transitions to sustainability. Res. Policy 2012, 41, 1025-1036. [CrossRef]

43. Geels, F.W. Low-carbon transition via system reconfiguration? A socio-technical whole system analysis of passenger mobility in Great Britain (1990-2016). Energy Res. Soc. Sci. 2018, 46, 86-102. [CrossRef]

44. Nææss, P.; Vogel, N. Sustainable urban development and the multi-Level transition perspective. Environ. Innov. Soc. Transit. 2012, 4, 36-50. [CrossRef]

45. Späth, P.; Rohracher, H. 'Energy regions': The transformative power of regional discourses on socio-technical futures. Res. Policy 2010, 39, 449-458. [CrossRef]

46. Pel, B. Trojan horses in transitions: A dialectical perspective on innovation 'capture'. J. Environ. Policy Plan. 2016, 18, 673-691. [CrossRef] 
47. Jørgensen, U. Mapping and navigating transitions - The multi-level perspective compared with arenas of development. Res. Policy 2012, 41, 996-1010. [CrossRef]

48. Kern, F.; Rogge, K.S.; Howlett, M. Policy mixes for sustainability transitions: New approaches and insights through bridging innovation and policy studies. Res. Policy 2019, 48, 103832. [CrossRef]

49. Meadowcroft, J. Engaging with the politics of sustainability transitions. Environ. Innov. Soc. Transit. 2011, 1, 70-75. [CrossRef]

50. Bulkeley, H.; Castan Broto, V.; Maassen, A. Low-carbon Transitions and the Reconfiguration of Urban Infrastructure. Urban Stud. 2014, 51, 1471-1486. [CrossRef]

51. Wolfram, M.; Frantzeskaki, N. Cities and Systemic Change for Sustainability: Prevailing Epistemologies and an Emerging Research Agenda. Sustainability 2016, 8, 144. [CrossRef]

52. Lawhon, M.; Murphy, J.T. Socio-technical regimes and sustainability transitions: Insights from political ecology. Prog. Hum. Geogr. 2012, 36, 354-378. [CrossRef]

53. Voß, J.; Bornemann, B. The Politics of Reflexive Governance: Challenges for Designing Adaptive Management and Transition Management. Ecol. Soc. 2011, 16, 9-32. [CrossRef]

54. Chilvers, J.; Longhurst, N. Participation in transition(s): Reconceiving public engagements in energy transitions as co-produced, emergent and diverse. J. Environ. Policy Plan. 2016, 18, 585-607. [CrossRef]

55. Shrivastava, M.; Ghosh, A.; Bhattacharyya, R.; Singh, S.D. Urban Pollution in India. In Urban Pollution; Charlesworth, S.M., Booth, C.A., Eds.; John Wiley \& Sons, Ltd.: Chichester, UK, 2018; pp. 341-356.

56. Mahato, S.; Ghosh, K.G. Short-term exposure to ambient air quality of the most polluted Indian cities due to lockdown amid SARS-CoV-2. Environ. Res. 2020, 188, 109835. [CrossRef] [PubMed]

57. Ganguly, T.; Selvaraj, K.L.; Guttikunda, S.K. National Clean Air Programme (NCAP) for Indian cities: Review and outlook of clean air action plans. Atmos. Environ. X 2020, 8, 100096. [CrossRef]

58. Shekhar, S. Vehicular Pollution in India: Laws and Reactions. SSRN Electron. J. 2015. [CrossRef]

59. SIAM Automobile Domestic Sales Trends. Available online: https://www.siam.in/statistics.aspx? mpgid=8\&pgidtrail=14 (accessed on 27 March 2021).

60. Govindaraj, E.; Karthikeyan, D.; Muthu, K. History of Emission standards in India-A Critical review. Int. J. Res. Anal. Rev. 2019, 6, 28-35.

61. WHO Ambient Air Pollution-a Major Threat to Health and Climate. Available online: https://www.who.int/airpollution/ambient/en/ \#: :text=Ambientairpollution-amajorthreattohealthandclimate\&text=Ambientairpollutionaccountsfor, qualitylevelsexceedWHOlimits (accessed on 27 March 2021).

62. Barman, S.C.; Singh, R.; Negi, M.P.S.; Bhargava, S.K. Assessment of urban air pollution and it's probable health impact. J. Environ. Biol. 2010, 31, 913-920. [CrossRef]

63. The World Air Quality Project Anand Vihar, Delhi, Delhi Air Pollution: Real-Time Air Quality Index. Available online: https: / / aqicn.org/ city/delhi/anand-vihar/ (accessed on 28 March 2021).

64. C40 Fossil Fuel Free Streets Declaration. Available online: https://www.c40.org/other/green-and-healthy-streets (accessed on 28 March 2021).

65. Burch, I.; Gilchrist, J.; Burch, B.I.; Gilchrist, J. Survey of Global Activity to Phase Out Internal Combustion Engine Vehicles; Center of Climate Protection: Santa Rosa, CA, USA, 2020.

66. Banister, D. Sustainable urban development and transport -a eurovision for 2020. Transp. Rev. 2000, 20, 113-130. [CrossRef]

67. Baggonkar, S.; Modi, A. Govt to leapfrog to BS-VI from 2020 | Business Standard News. Available online: https://www.businessstandard.com/article/economy-policy/govt-to-leapfrog-to-bs-vi-from-2020-116010700054_1.html (accessed on 28 March 2021).

68. Jha, S. Govt. to Implement BS-VI Norms by 2020 - The Hindu. Available online: https: / /www.thehindu.com/business/Govt.-toimplement-BS-VI-norms-by-2020/article13984521.ece (accessed on 28 March 2021).

69. Roychowdhury, A.; Chattopadhyaya, V. Bharat Stage VI (BS-VI) Readiness and Roadmap in India; Round Table on BSVI Readiness: New Delhi, India, 2019.

70. Patil, A.A.; Joshi, R.R.; Dhavale, A.J.; Balwan, K.S. Review of Bharat Stage 6 Emission Norms. Int. Res. J. Eng. Technol. 2019, 6, 1359-1361.

71. Planko, J.; Cramer, J.; Hekkert, M.P.; Chappin, M.M.H.; Planko, J.; Cramer, J.; Hekkert, M.P.; Chappin, M.M.H. Technology Analysis \& Strategic Management Combining the technological innovation systems framework with the entrepreneurs ' perspective on innovation. Technol. Anal. Strateg. Manag. 2017, 29, 614-625. [CrossRef]

72. Kolleck, N.; Jörgens, H.; Well, M. Levels of Governance in Policy Innovation Cycles in Community Education: The Cases of Education for Sustainable Development and Climate Change Education. Sustainability 2017, 9, 1966. [CrossRef]

73. Henshilwood, E.; Swilling, M.; Naidoo, M.L. A transdisciplinary inquiry into sustainable automobility transitions: The case of an urban enclave in Cape Town. Int. J. E -Plan. Res. 2019, 8, 13-37. [CrossRef]

74. Kozinets, R.V. Marketing Netnography: Prom/ot(Ulgat)ing a New Research Method. Methodol. Innov. Online 2012, 7, 37-45. [CrossRef]

75. Ampofo, L.; Collister, S.; O'Loughlin, B.; Chadwick, A. Text Mining and Social Media: When Quantitative Meets Qualitative and Software Meets People. In Innovations in Digital Research Methods; Halfpenny, P., Procter, R., Eds.; SAGE Publications Limited: London, UK, 2015; pp. 161-192. 
76. Ananiadou, S.; Rea, B.; Okazaki, N.; Procter, R.; Thomas, J. Supporting Systematic Reviews Using Text Mining. Soc. Sci. Comput. Rev. 2009, 27, 509-523. [CrossRef]

77. Rajput, H. Social Media and Politics in India: A Study on Twitter Usage among Indian Political Leaders. Asian J. Multidiscip. Stud. 2014, 2, 63-69.

78. Ahmed, S.; Cho, J.; Jaidka, K. Leveling the playing field: The use of Twitter by politicians during the 2014 Indian general election campaign. Telemat. Inform. 2017, 34, 1377-1386. [CrossRef]

79. Bouvier, G. What is a discourse approach to Twitter, Facebook, YouTube and other social media: Connecting with other academic fields? J. Multicult. Discourses 2015, 10, 149-162. [CrossRef]

80. Livingstone, S. Taking risky opportunities in youthful content creation: Teenagers' use of social networking sites for intimacy, privacy and self-expression. New Media Soc. 2008, 10, 393-411. [CrossRef]

81. Suárez-Rico, Y.; Gómez-Villegas, M.; García-Benau, M. Exploring Twitter for CSR Disclosure: Influence of CEO and Firm Characteristics in Latin American Companies. Sustainability 2018, 10, 2617. [CrossRef]

82. Heale, R.; Forbes, D. Understanding triangulation in research. Evid. Based. Nurs. 2013, 16, 98. [CrossRef] [PubMed]

83. Graham, T.; Broersma, M.; Hazelhoff, K.; van 't Haar, G. Between broadcasting political messages and interacting with voters: The use of Twitter during the 2010 UK general election campaign. Inf. Commun. Soc. 2013, 16, 692-716. [CrossRef]

84. Gee, J.P. How to do Discourse Analysis: A Toolkit, 2nd ed.; Routledge: London, UK, 2014.

85. Mohammadi, M.; Javadi, J. A Critical Discourse Analysis of Donald Trump's Language Use in US Presidential Campaign, 2016. Int. J. Appl. Linguist. English Lit. 2017, 6, 1. [CrossRef]

86. Hamaguchi, T. Prospects for Self-Reliance and Indigenisation in Automobile Industry: Case of Maruti-Suzuki Project. Econ. Polit. Wkly. 1985, 20, M115-M122.

87. Kathuria, S. Commercial Vehicles Industry in India-A Case History, 1928-1987. Econ. Polit. Wkly. 1987, $22,1809-1823$.

88. Bhave, P.; Kulkarni, N. Air Pollution and Control Legislation in India. J. Inst. Eng. Ser. A 2015, 96, 259-265. [CrossRef]

89. Beckerman, W. Economic Development and the Environment: Conflict of Complementarity? The World Bank Policy Research Working Paper Series: Washington, DC, USA, 1992.

90. Ranawat, M.; Tiwari, R. Influence of Government Policies on Industry Development: The Case of India's Automotive Industry; Hamburg University of Technology (TUHH), Institute for Technology and Innovation Management: Hamburg, Germany, 2009.

91. Thakurta, P.G. Ideological Contradictions in an Era of Coalitions: Economic Policy Confusion in the Vajpayee Government. Glob. Bus. Rev. 2002, 3, 201-223. [CrossRef]

92. Sen, G. Million Cars for Billion People; Vemuri, S., Ed.; Platinum Press: Mumbai, India, 2014.

93. George, S.; Jha, R.; Nagarajan, H. The Evolution and Structure of the Two-wheeler Industry in India. Int. J. Transp. Econ. 2002, 29, 63-89. [CrossRef]

94. ACMA The Automotive Component Manufacturers Association of India-ACMA. Available online: https://www.acma.in/ (accessed on 28 March 2021).

95. SIAM Society of Indian Automobile Manufactures. Available online: https:/ / www.siam.in/members.aspx?mpgid=1\&pgidtrail=4 (accessed on 28 March 2021).

96. FADA About FADA-FADA India. Available online: http:/ / www.fadaindia.org/about-fada.html (accessed on 28 March 2021).

97. ASDC Automotive Skills Development Council: Automotive Training Certification Centre-ASDC. Available online: https: / /www.asdc.org.in/ (accessed on 28 March 2021).

98. Supreme Court of India M.C. Mehta vs Union Of India on 24 October, 2018. Available online: https://indiankanoon.org/doc/ 73307198/?_cf_chl_jschl_tk_=99ff6f2ccfb0126a2b2fa4446979491edc28fb2b-1616939067-0-Ab8pAzQ12CuaplwxLpnMPGWs4 SHPFjoOPfKVBFn0c2uWXPQwRIG5-XhigfKPKasEfyBERMkfcTRpHbk2B-Zy33UF2P13ATSZoAAS5UAPXL7aV72CBJiGrgFeUmeW6-SMC137yNZhN_2YAwHfOdTwTyfbCd_VQzBxJauz9sUCuD7Iq_PGMZDH3gVaYV1VV73EZVA0qo4G8OF5 o5qSTe58HUT9C83-7oCMOn4Us80jZylJ1-pTSCSPFVjBnnxRRcClX2jojDVirmtV5jLGdgK2LZ-VnftGuWd-SLpkiLje9DYn5RuNOeQUOxgUzoBl3jvbGm2I5HBd8LGRX9YC5Q6kGWqWi9kgVskCeZSuWdWMhSMV_bWYm_3SEi9bEf2tmxpDo_ ZTyR0oLj016DAZ1J-Ks (accessed on 28 March 2021).

99. The Times Of India Passenger Vehicle Sales Fall for Ninth Straight Month, Dive 31\% in July. Available online: https: / / timesofindia.indiatimes.com/business/india-business/passenger-vehicle-sales-fall-for-ninth-straight-month-dive-31-injuly/articleshow /70654709.cms?utm_source=contentofinterest\&utm_medium=text\&utm_campaign=cppst (accessed on 28 March 2021).

100. The Economic Times Budget 2019: Pollution Control in Focus, Environment Ministry Gets Rs 2,954 Crore. Available online: https:/ / economictimes.indiatimes.com/news/economy/policy/budget-2019-pollution-control-in-focus-environmentministry-gets-rs-2954-crore/articleshow/70095085.cms (accessed on 28 March 2021).

101. Mukherjee, S. India's New Passenger Vehicle Financing Market to Double to Rs 1600 Billion by 2020-The Economic Times. Available online: https:/ / economictimes.indiatimes.com/industry/auto/indias-new-passenger-vehicle-financing-market-todouble-to-rs-1600-billion-by-2020/articleshow /57269910.cms?from=mdr (accessed on 28 March 2021).

102. Hadkar, C. Supreme Court Allow BS4 Registrations - MotorOctane. Available online: https://motoroctane.com/news/207604 -bs4-registrations (accessed on 28 March 2021).

103. Hudson, B.; Hunter, D.; Peckham, S. Policy failure and the policy-implementation gap: Can policy support programs help? Policy Des. Pract. 2019, 2, 1-14. [CrossRef] 
104. Berkhout, F. Technological regimes, path dependency and the environment Technological regimes, path dependency and the environment. Glob. Environ. Chang. 2002, 12, 1-4. [CrossRef]

105. Berggren, C.; Magnusson, T.; Sushandoyo, D. Transition pathways revisited: Established firms as multi-level actors in the heavy vehicle industry. Res. Policy 2015, 44, 1017-1028. [CrossRef]

106. Shiroyama, H.; Kajiki, S. Case Study of Eco-town Project in Kitakyushu: Tension Among Incumbents and the Transition from Industrial City to Green City. In Governance of Urban Sustainability Transitions; Springer Japan: Tokyo, Japan, 2016 ; pp. 113-132.

107. Bajwa, N. Automobile Industry in India-Auto Sector Growth Analysis. Available online: https:/ /www.investindia.gov.in/sector/ automobile (accessed on 28 March 2021).

108. Markandya, A.; Sampedro, J.; Smith, S.J.; Van Dingenen, R.; Pizarro-Irizar, C.; Arto, I.; González-Eguino, M. Health co-benefits from air pollution and mitigation costs of the Paris Agreement: A modelling study. Lancet Planet. Heal. 2018, 2, e126-e133. [CrossRef]

109. Backhaus, J. Intermediaries as Innovating Actors in the Transition to a Sustainable Energy System. Cent. Eur. J. Public Policy 2010, 4, 86-109.

110. Flanagan, K.; Uyarra, E.; Laranja, M. Reconceptualising the "policy mix" for innovation. Res. Policy 2011, 40, 702-713. [CrossRef] 